\title{
Synthetical evaluation of ecological value of university campuses
}

\author{
Hong Wei Chen*
}

Office of Campus Construction, Tianjin Polytechnic University, Tianjin, 300160, CHINA

*Corresponding Author: e-mail: tjchenhw@sohu.com, Tel +86-22-83956800

\begin{abstract}
In this paper, a reasonable ecological value evaluation system for the ecological environment of a university campus was established based on fuzzy analytic hierarchy process (FAHP). The system contains 2 criteria, 13 factors and 55 sub-factors. Using FAHP combined with compiling the Mathematica program, we determined the weights of the criteria and factors, which could reflect the human thinking style. In order to verify the system, a model was presented, and the result obtained was regarded as reasonable. The evaluation system and the model can be used in other similar assessments for their feasibility.
\end{abstract}

Keywords: ecotype campus; fuzzy analytic hierarchy process (FAHP); fuzzy synthetical evaluation; Mathematica

\section{Introduction}

In recent years, there are many universities which are busy in establishing new campus in China. A great deal of effort has been made for managing construction on ecotype campus. As we know, there are a great number of ecotype campuses, which have been established around the world. They are so-called green campus, which can utilize the resources more effectively than the traditional architectures, in the meanwhile, the environment is cleaner and more beautiful. Generally, the green ecotype campus should possess the features as follows (Zhang, 2006; Conway et al., 2008). (1) efficient conversion system; (2) efficient circulation system, which contains transportation system, information transmission system, rationally distributed services system, sewerage system and so on; (3) high quality environmental state; (4) Multi-functional three dimensional green system; (5) high level management system.

To develop ecotype campus, we must set up an ecological value evaluating system of the campus, which can guide the developers to establish an ecotype campus. The evaluation on the ecotype campus has been held in many countries around the world, but the problem is that less attention paid on the evaluation of the ecological value or the methods used in the work have some limitations. For example, some scholars finished the evaluation by using AHP (Analytic Hierarchy Process) (Zhang and Zhan, 2004) or FCE (fuzzy comprehensive evaluation) (Han and Zhang, 2003) based on AHP respectively, the methods used can do the evaluation from the quantitative and qualitative aspects, but to some extent, the methods may lose some information of the people's thinking preference.

In this paper, we will evaluate the ecological value of ecotype campus by using FAHP and fuzzy comprehensive evaluation. FAHP was also applied in determining the weights $\left(W_{A}\right)$ of the criteria given by experts.

Fuzzy AHP methodology which is originally based on the concept of fuzzy set introduced by Zaddeh (1965) can handle the inherent uncertainty and reflect the human thinking style. Decision makers usually find that it is more confident to propose interval judgments than fixed value judgments. The reason is that it is difficult to make people's preference explicit in a complex process (Kahraman et al., 2003). That is the reason why we substituted triangular fuzzy numbers (TFNs) matrix for the pair-wise comparision matrix to analyze criteria measurement and determine the fuzzy consensus problem in assessment. 


\section{Theories and Methods}

\subsection{Fuzzy sets and Fuzzy Numbers}

Definition 1. (Fuzzy sets)

Let $X$ be a universe of discourse, $\tilde{A}$ be a fuzzy subset of $X$,such that for all $x \in X$, there is a number $\mu_{\tilde{A}}(x) \in[0,1]$, which is assigned to represent the membership of $x$ to $\tilde{A}$, and $\mu_{\tilde{A}}(x)$ is called the membership of $\tilde{A}$ (Zaddeh, 1965).

Definition 2 (Fuzzy number)

A fuzzy number $\tilde{A}$ is a normal and convex fuzzy subset of $X$, which implies that $\forall x_{1} \in \tilde{A}, x_{2} \in \tilde{A}, \alpha \in[0,1]$, then $\mu_{\tilde{A}}\left(\alpha x_{1}+(1-\alpha) x_{2}\right) \geq \min \left(\mu_{\tilde{A}}\left(x_{1}\right), \mu_{\tilde{A}}\left(x_{2}\right)\right)$.

Definition 3 (Triangular fuzzy number)

A triangular fuzzy number $\tilde{A}$ can be defined by a triplet $(l, m, n)$. The membership function is defined as

$$
\mu_{\tilde{A}}(x)= \begin{cases}(x-l) /(m-l), & l \leq x \leq m, \\ (n-x) /(n-m), & m \leq x \leq n, \\ 0, & \text { otherwise }\end{cases}
$$

The addition, multiplication, subtraction and divisions of the triangular fuzzy numbers are expressed as follow: The operations (Zimmermann, 1987) for FTNs are defined as follows:

$$
\left(a_{1}, b_{1}, c_{1}\right) \oplus\left(a_{2}, b_{2}, c_{2}\right)=\left(a_{1}+a_{2}, b_{1}+b_{2}, c_{1}+c_{2}\right),\left(a_{1}, b_{1}, c_{1}\right) \otimes\left(a_{2}, b_{2}, c_{2}\right)=\left(a_{1} \times a_{2}, b_{1} \times b_{2}, c_{1} \times c_{2}\right) .
$$

\subsection{Defuzzification}

Various defuzzication methods are available, one method proposed in articles (Lious and Wang, 1992; Hus and Nian, 1997) is the following. Let $A_{i j}=\left(a_{i j}\right)_{m \times n}, a_{i j}=\left(L_{i j}, M_{i j}, U_{i j}\right)(i=1,2 \cdots, m, j=1,2, \cdots, n)$, then

$$
\left(a_{i j}^{\alpha}\right)^{\lambda}=\left[\lambda \cdot L_{i j}^{\alpha}+(1-\lambda) \cdot U_{i j}^{\alpha}\right]
$$

Where $0 \leq \lambda \leq 1,0 \leq \alpha \leq 1, L_{i j}^{\alpha}=\left(M_{i j}-L_{i j}\right) \cdot \alpha+L_{i j}$ represents the left-end value of $\alpha$-cut for $a_{i j} U_{i j}^{\alpha}=U_{i j}-\left(U_{i j}-M_{i j}\right) \cdot \alpha$ represents the right-end value of for $\alpha$-cut for $a_{i j}$. This method can reflect the preference $(\alpha)$ and risk tolerance $(\lambda)$ of decision makers explicitly. $A_{i j}$ is defuzzied, and $\left(A^{\alpha}\right)^{\lambda}=\left[\left(a_{i j}^{\alpha}\right)^{\lambda}\right]$.

Another method called extent FAHP is utilized recently, which was originally introduced by Chang (1996). Let $O=\left\{o_{1}, o_{2}, \cdots, o_{n}\right\}$ be an object set, and $G=\left\{g_{1}, g_{2}, \cdots, g_{m}\right\}$ be a goal set. According to the method of Chang's extent analysis for each goal performed respectively, $m$ extent analysis values for each object can be obtained as the following signs: $M_{g i}^{1}, M_{g i}^{2}, \cdots, M_{g i}^{m}, i=1,2, \cdots, n, j=1,2, \cdots, m$, where the $M_{g i}^{j}=\left(l_{i j}, m_{i j}, u_{i j}\right)$, are all TFNs. The steps of Chang's extent analysis can be given as follows:

Step 1. The value of fuzzy synthetic extent with respect to the ith object is defined as

$$
S_{i}=\sum_{j=1}^{m} M_{g i}^{j} \otimes\left[\sum_{i=1}^{n} \sum_{j=1}^{m} M_{g i}^{j}\right]^{-1},
$$

To obtain $\sum_{j=1}^{m} M_{g i}^{j}$, we perform the fuzzy addition operation, i.e.

$$
\sum_{j=1}^{m} M_{g i}^{j}=\left(\sum_{j=1}^{m} l_{i j}, \sum_{j=1}^{m} m_{i j}, \sum_{j=1}^{m} u_{i j}\right),
$$

and to obtain $\left[\sum_{i=1}^{n} \sum_{j=1}^{m} M_{g i}^{j}\right]^{-1}$, we perform the fuzzy addition operation of $M_{g i}^{j}(j=1,2, \cdots, m)$ values such that

$$
\sum_{i=1}^{n} \sum_{j=1}^{m} M_{g i}^{j}=\left(\sum_{i=1}^{n} \sum_{j=1}^{m} l_{i j}, \sum_{i=1}^{n} \sum_{j=1}^{m} m_{i j}, \sum_{i=1}^{n} \sum_{j=1}^{m} u_{i j},\right),
$$

and then the inverse of the above is computed, such as 


$$
\left[\sum_{i=1}^{n} \sum_{j=1}^{m} M_{g i}^{j}\right]^{-1}=\left(\sum_{i=1}^{n} \sum_{j=1}^{m} l_{i j}, \sum_{i=1}^{n} \sum_{j=1}^{m} m_{i j}, \sum_{i=1}^{n} \sum_{j=1}^{m} u_{i j},\right)^{-1},
$$

Step 2. Let $M_{1}=\left(l_{1}, m_{1}, u_{1}\right)$ and $M_{2}=\left(l_{2}, m_{2}, u_{2}\right)$ be two TFNs, then we define the degree of possibility of

$$
\begin{aligned}
& M_{2}=\left(l_{2}, m_{2}, u_{2}\right) \geq M_{1}=\left(l_{1}, m_{1}, u_{1}\right) \text { as } \\
& \qquad V\left(M_{2} \geq M_{1}\right)=\sup _{y \geq x}\left[\min \left(\mu_{M_{1}}(x), \mu_{M_{2}}(y)\right)\right],
\end{aligned}
$$

it can be expressed equivalently as follow:

$$
V\left(M_{2} \geq M_{1}\right)=\mu_{M_{2}}(d)=\left\{\begin{array}{lc}
1, & \text { if } m_{2} \geq m_{1} \\
0, & \text { if } l_{1} \geq u_{2} \\
\frac{l_{1}-u_{2}}{\left(m_{2}-u_{2}\right)-\left(m_{1}-l_{1}\right)}, & \text { otherwise }
\end{array}\right.
$$

Where $d$ is the ordinate of the highest intersection point between $\mu_{M_{1}}$ and $\mu_{M_{2}}$. To compare $M_{1}$ and $M_{2}$, we need both the values of $V\left(M_{1} \geq M_{2}\right)$ and $V\left(M_{2} \geq M_{1}\right)$.

Step 3. The degree of possibility for a convex fuzzy number to be greater than $k$ convex fuzzy numbers $M_{i}(i=1,2, \cdots, k)$, can be defined by

$$
V\left(M \geq M_{1}, M_{2}, \cdots, M_{k}\right)=V\left[\left(M \geq M_{1}\right) \text { and }\left(M \geq M_{2}\right) \text { and } \cdots \text { and }\left(M \geq M_{k}\right)\right]=\min V\left(M \geq M_{i}\right), \quad i=1,2,3, \cdots, k
$$

Assume that

$$
d^{\prime}\left(A_{i}\right)=\min V\left(S_{i} \geq S_{k}\right) \text {,for } k=1,2, \cdots, n ; k \neq i
$$

Then the weight vector is given by

$$
W^{\prime}=\left(d^{\prime}\left(A_{1}\right), d^{\prime}\left(A_{2}\right), \cdots, d^{\prime}\left(A_{n}\right)\right)^{T}
$$

Where $A_{i}(i=1,2, \cdots, n)$ are $n$ elements.

Step 4. Via normalization, the normalized weight vectors are $W=\left(d\left(A_{1}\right), d\left(A_{2}\right), \cdots, d\left(A_{n}\right)\right)^{T}$, where $W$ is a non-fuzzy vector.

\section{Applications}

The purpose of our work is to assess the ecological value of university campuses. We choose a university campus in Tianjin, a large city in China, as an example. By using fuzzy comprehensive evaluation based on FAHP i.e., considering all the criteria about the problem, we get a constructive and reasonable result on assessment of university campus

The proposed FAHP model to assess the ecological value of university campus is composed of these following steps.

3.1 Establish the decision group and collect data

We obtained the data by using synthetical questionnaire and field survey. Thus some data were from the faculty in the university. The other data of some technical sub-factors were obtained by field survey. Considering the different background of knowledge and living experiences, we selected some faculty, some scientists, and some environmental experts to form the panel of evaluation. 3.2 Develop a hierarchical structure of the assessment problem

According to characteristics of campus, the evaluation system of the ecological value is divided into target layer, criteria layer, factors, sub-factors, and thus a four-level- hierarchical model is devised (Table.1). In the model, the target level is the ecological value of university campuses, the goal is divided into two main criteria, which are natural ecological value and socio-ecological value, many factors of the two criteria are considered in order to measure the two criteria.

3.3 Determine the relative weights of each criterion by using pair-wise comparision matrixes

The triangular fuzzy numbers are used to present the fuzzy opinions. The fuzzy scale (Kahraman et al., 2006) regarding relative importance to measure the relative weights is listed in Table.2. After all the decision makers compared the factors with respect to main-factors, we obtained the results. We integrate the weights of the decision makers to obtain the pair-wise comparison matrix 
by using average weights. The weights of criterion B1 and B2 are 0.7 and 0.3 respectively, which are determined by experts subjectively. Table. 3 and Table. 5 are the pair-wise comparison matrix of two criteria of the object.

Table 1. The Hierarchy of the Problem

\begin{tabular}{|c|c|c|c|}
\hline $\begin{array}{l}\text { Target } \\
\text { (A) }\end{array}$ & $\begin{array}{l}\text { Criteria } \\
(B)\end{array}$ & Factors(C) & Sub-factors(D) \\
\hline \multirow{13}{*}{ 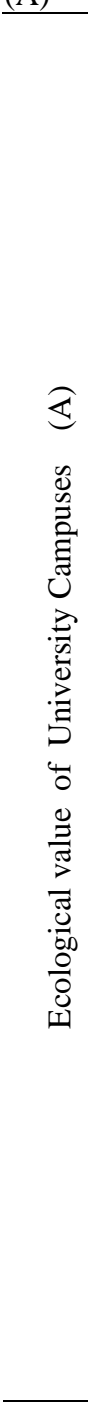 } & \multirow{10}{*}{$\begin{array}{l}\text { Natural } \\
\text { ecological } \\
\text { value } \\
\text { (B1) }\end{array}$} & $\begin{array}{l}\text { Campus planning } \\
\text { (C01) }\end{array}$ & $\begin{array}{l}\text { Coordination (D011); Land allocation (D012); Building density (D013); building plot ratio } \\
\text { (D014); Natural lighting proportion (D015) }\end{array}$ \\
\hline & & $\begin{array}{l}\text { Traffic organization } \\
\text { (C02) }\end{array}$ & $\begin{array}{l}\text { Transportation Convenience for students (D021); Transportation Convenience for faculty } \\
\text { (D022) ; Transportation Convenience for staff (D023) } \\
\text { Road constitution (D024); Barrier-free design of roads (D025); Parking facilities (D026) }\end{array}$ \\
\hline & & $\begin{array}{l}\text { Architectural } \\
\text { Composition (C03) }\end{array}$ & $\begin{array}{l}\text { Reasonable distance of residence(D031); Building facing (D032); Housing household } \\
\text { (D033); Building Roof (D034) } \\
\text { Light Pollution (D035); Outdoor landscape visual accessibility(D036); Visual privacy (D037) }\end{array}$ \\
\hline & & $\begin{array}{l}\text { Environmental } \\
\text { Greening (C04) }\end{array}$ & $\begin{array}{l}\text { Greening rate (D041); the ratio of the ecological land of the floor (D042); utilization ratio of } \\
\text { the natural material (D043) } \\
\text { Rainwater stagnation time (D044); Actual degree of abundance of plant configuration (D045) }\end{array}$ \\
\hline & & $\begin{array}{l}\text { Building energy } \\
\text { conservation } \\
\text { (C05) }\end{array}$ & $\begin{array}{l}\text { The building shape coefficient(D051); The average coefficient of heat transfer of the } \\
\text { wall(D052); Area ratio of window to wall (D053) } \\
\text { The ratio of building energy efficiency (D054); utilization ratio of Material 3R (D055) }\end{array}$ \\
\hline & & \begin{tabular}{|l|} 
Atmospheric \\
Environment(C06)
\end{tabular} & $\begin{array}{l}\text { Total Suspended Particulates TSP (D061); Temperature control (D062); Humidity control } \\
\text { (D063) }\end{array}$ \\
\hline & & \begin{tabular}{|ll} 
Acoustical & \\
Environment $\quad(\mathrm{C} 07)$ \\
\end{tabular} & $\begin{array}{l}\begin{array}{l}\text { Daytime noise levels (D071); Night-time noise levels (D072); Noise isolation measures } \\
\text { (D073) }\end{array} \\
\end{array}$ \\
\hline & & $\begin{array}{l}\text { Water Environment } \\
\text { (C08) }\end{array}$ & $\begin{array}{l}\text { the rate of sewage treatment reaching the standard (D081); The rate of water reuse (D082); } \\
\text { Rainwater utilization (D083) } \\
\text { Water quality standards (D084); Utilization of water-saving appliances (D085); Green water } \\
\text { (D086); Landscape water (D087) }\end{array}$ \\
\hline & & $\begin{array}{l}\text { Light Environment } \\
\text { (C09) }\end{array}$ & $\begin{array}{l}\text { Sun-room ratio (D091); Number of rooms in natural light (D092); Number of rooms with } \\
\text { non-light pollution (D093) }\end{array}$ \\
\hline & & $\begin{array}{l}\text { Thermal Environment } \\
\text { (C10) }\end{array}$ & $\begin{array}{l}\text { Building heating ,Air conditioning and hot water supply in the proportion of green energy } \\
\text { use (D101) } \\
\text { heating, air conditioning, hot water trinity of thermal environment technology coverage } \\
\text { (D102) }\end{array}$ \\
\hline & \multirow{3}{*}{$\begin{array}{l}\text { Socio- } \\
\text { ecological } \\
\text { value } \\
\text { (B2) }\end{array}$} & Campus culture (C11) & $\begin{array}{l}\text { the impact on the surrounding urban space and cultural landscape (D111); the impact of the } \\
\text { campus building on the regional } \\
\text { cultural characteristics (D112); the impacts of the campus building on historical relics } \\
\text { (D113) }\end{array}$ \\
\hline & & $\begin{array}{l}\text { Campus Ma } \\
\text { (C12) }\end{array}$ & $\begin{array}{l}\text { Information services (D121); Property management (D122); Waste management and disposal } \\
\text { (D123) }\end{array}$ \\
\hline & & & vironment (D132); C \\
\hline
\end{tabular}

Table 2. Triangular Fuzzy Conversion Scale

\begin{tabular}{l|l|l}
\hline Linguistic scale & $\begin{array}{l}\text { Triangular } \\
\text { fuzzy scale }\end{array}$ & $\begin{array}{l}\text { Triangular fuzzy } \\
\text { reciprocal scale }\end{array}$ \\
\hline Just equal & $(1,1,1)$ & $(1,1,1)$ \\
Equally important & $(1 / 2,1,3 / 2)$ & $(2 / 3,1,2)$ \\
Weakly important & $(1,3 / 2,2)$ & $(1 / 2,2 / 3,1)$ \\
Strongly more important & $(3 / 2,2,5 / 2)$ & $(2 / 5,1 / 2,2 / 3)$ \\
Very strongly more important & $(2,5 / 2,3)$ & $(1 / 3,2 / 5,1 / 2)$ \\
Absolutely more important & $(5 / 2,3,7 / 2)$ & $(2 / 7,1 / 3,2 / 5)$ \\
\hline
\end{tabular}

Table 3. Pair-Wise Comparison Matrix of Factors of B2

\begin{tabular}{c|ccc}
\hline & C11 & C12 & C13 \\
\hline C11 & $(1,1,1)$ & $(2 / 5,1 / 2,2 / 3)$ & $(2,5 / 2,3)$ \\
C12 & $(3 / 2,2,5 / 2)$ & $(1,1,1)$ & $(1 / 3,2 / 5,1 / 2)$ \\
C13 & $(1 / 3,2 / 5,1 / 2)$ & $(2,5 / 2,3)$ & $(1,1,1)$ \\
\hline
\end{tabular}




\subsection{Determine the weights of the criteria and factors}

We use the extent FAHP method to determine the weights. Firstly, synthesis values must be worked out. From Table.3, synthesis values are calculated as in Eq.(3), the calculating process of the weights of the criteria B1 as follow:

$S_{\text {C01 }}=(12.352,15.5,19.567) \otimes\left(157.835^{-1}, 121.699^{-1}, 94.724^{-1}\right)=(0.078,0.127,0.207)$.

By similar calculation, we can obtained the results as $S_{C 02}=(0.078,0.129,0.209), S_{C 03}=(0.051,0.093,0.158)$,

$S_{C 04}=(0.054,0.089,0.151), S_{C 05}=(0.063,0.102,0.163), S_{C 06}=(0.042,0.068,0.129), S_{C 07}=(0.045,0.075,0.128)$,

$S_{C 08}=(0.058,0.101,0.164), S_{C 09}=(0.068,0.109,0.185)$, and $S_{C 10}=(0.065,0.105,0.172)$.

After calculating the degree of possibility by using Eq.(8), we obtained the weight vector by Eq.(9) as follows:

$d^{\prime}\left(C_{01}\right)=\min V\left(S_{\mathrm{CO} 1}>S_{\mathrm{CO} 2}, S_{\mathrm{CO} 3}, S_{\mathrm{CO}}, S_{\mathrm{CO} 5}, S_{\mathrm{CO} 0}, S_{\mathrm{CO} 7}, S_{\mathrm{CO}}, S_{\mathrm{CO} 9}, S_{\mathrm{C} 10}\right)=0.989$. With the similar calculation, we obtained

$d^{\prime}\left(C_{02}\right)=\min V\left(S_{C 02}>S_{C 01}, S_{C 03}, S_{C 04}, S_{C 05}, S_{C 06}, S_{C 07}, S_{C 08}, S_{C 09}, S_{C 10}\right)=1, d^{\prime}\left(C_{03}\right)=0.694, d^{\prime}\left(C_{04}\right)=0.65, d^{\prime}\left(C_{05}\right)=0.764, d^{\prime}\left(C_{06}\right)=0.461$,

$d^{\prime}\left(C_{07}\right)=0.486, d^{\prime}\left(C_{08}\right)=0.76, d^{\prime}\left(C_{09}\right)=0.843, d^{\prime}\left(C_{10}\right)=0.802$.

These values can yield the following weights vector: $W^{\prime}=(0.989,1 ., 0.694,0.65,0.764,0.461,0.486,0.76,0.843,0.802) \cdot$ Via normalization, the weights of the factors are obtained: $W_{B 1}=(0.133,0.134,0.093,0.087,0.103,0.062,0.065,0.102,0.113,0.108)$. In the same way, we obtained the weights of the factor B2 $W_{B 2}=(0.277,0.369,0.354)$. All results are collected in Table 4.

\subsection{Fuzzy assessment}

According to the hierarchy of the problem, we should set up a multi-grade fuzzy comprehensive evaluation model. Fuzzy comprehensive evaluation includes the following process:

3.5.1 Determine the factor set, which has been determined in the previous analysis.

3.5.2 Determine the weights of factors by using FAHP.

Using the method described above, similar procedures are carried out to calculate relative importance weight of the sub-factors with respect to factors. The weights of the factors (C01-C12) are shown in Table.4.

3.5.3 Determine the assessment level, After questionnaire survey, we grade the evaluation system with four levels: excellent ( $\star \star \star \star)$, good $(\star \star \star)$, moderate $(\star \star)$, ineligible $(\star)$.

3.5.4 Determine subordinate relatio, set up fuzzy evaluation matrix

Members in the decision group are required to provide their judgments on the basis of their knowledge and expertise for each sub-factor at the bottom level in the hierarchy. If we denote the membership degrees of excellent, good, moderate and ineligible with respect to each factor by $v_{i j 1}, v_{i j 2}, v_{i j 3}, v_{i j 4}$, the membership degree on each factor by the some experts and representatives of faculty and students are $r_{i j}=\left(\begin{array}{llll}v_{i j 1} & v_{i j 2} & v_{i j 3} & v_{i j}\end{array}\right)$, the fuzzy evaluation matrix is $R=\left(r_{i j}\right)_{n \times m}$.

\subsubsection{Fuzzy comprehensive evaluation.}

The process of fuzzy comprehensive evaluation is mainly the composition of $W$ and fuzzy matrix, the weights of the factors and the evaluation results of the sub-factors level by an expert (or a group) as shown in Table. 4. The steps of the fuzzy comprehensive evaluation are as follows:

Step1. First-class fuzzy comprehensive evaluation

For the factors, we obtained: $W_{C 03}=(0.155,0.134,0.172,0.189,0.118,0.056,0.176)$

$$
R_{C 03}=\left(\begin{array}{cccc}
0.61 & 0.16 & 0.14 & 0.09 \\
0.25 & 0.30 & 0.27 & 0.18 \\
0.66 & 0.14 & 0.12 & 0.08 \\
0.32 & 0.27 & 0.24 & 0.16 \\
0.18 & 0.33 & 0.30 & 0.20 \\
0.18 & 0.33 & 0.29 & 0.20 \\
0.24 & 0.30 & 0.27 & 0.18
\end{array}\right), \quad R_{3}=W_{C 03} \circ R_{C 03}=(0.376,0.25,0.223,0.149) \text {. }
$$

where $R_{C 03}$ is the fuzzy evaluation matrix of the factors. $\circ$ is defined as weighted average. Similarly, we obtain $R_{i}(i=2, \cdots, 12)$. 
Table 4. Weights and Evaluation Results of the Second Indexes Level

\begin{tabular}{|c|c|c|c|c|c|c|c|c|c|}
\hline \multirow{2}{*}{ d } & \multirow{2}{*}{ B } & \multirow{2}{*}{ C } & \multirow[b]{2}{*}{ weight } & \multirow[b]{2}{*}{ D } & \multirow[b]{2}{*}{ weight } & \multicolumn{4}{|c|}{ Evaluation value } \\
\hline & & & & & & 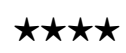 & $\star \star \star \star$ & $\star \star$ & $\star$ \\
\hline \multirow{13}{*}{ 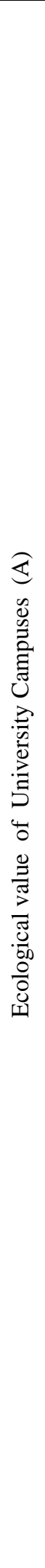 } & \multirow{10}{*}{$\begin{array}{l}\text { Natural } \\
\text { ecological } \\
\text { value } \\
\text { (B1) }\end{array}$} & $\begin{array}{l}\text { Campus } \\
\text { planning } \\
\text { ( C01) }\end{array}$ & 0.133 & \begin{tabular}{|l} 
D011 \\
D012 \\
D013 \\
D014 \\
D015
\end{tabular} & $\begin{array}{l}0.345 \\
0.021 \\
0.117 \\
0.185 \\
0.332\end{array}$ & $\begin{array}{l}0.8 \\
0.44 \\
0.07 \\
0.46 \\
0.32\end{array}$ & $\begin{array}{l}0.08 \\
0.22 \\
0.37 \\
0.22 \\
0.27\end{array}$ & $\begin{array}{l}0.07 \\
0.2 \\
0.34 \\
0.19 \\
0.24\end{array}$ & $\begin{array}{l}0.05 \\
0.13 \\
0.22 \\
0.13 \\
0.16\end{array}$ \\
\hline & & $\begin{array}{l}\text { Traffic } \\
\text { organization } \\
\text { (C02) }\end{array}$ & 0.134 & \begin{tabular}{|l} 
D021 \\
D022 \\
D023 \\
D024 \\
D025 \\
D026
\end{tabular} & $\begin{array}{l}0.083 \\
0.271 \\
0.269 \\
0.106 \\
0.172 \\
0.099\end{array}$ & $\begin{array}{l}0.37 \\
0.16 \\
0.06 \\
0.24 \\
0.51 \\
0.64\end{array}$ & $\begin{array}{l}0.25 \\
0.34 \\
0.38 \\
0.3 \\
0.2 \\
0.15\end{array}$ & $\begin{array}{l}0.23 \\
0.3 \\
0.34 \\
0.27 \\
0.18 \\
0.13\end{array}$ & $\begin{array}{l}0.15 \\
0.2 \\
0.23 \\
0.18 \\
0.12 \\
0.09\end{array}$ \\
\hline & & $\begin{array}{l}\text { Architectural } \\
\text { Composition } \\
\text { (C03) }\end{array}$ & 0.093 & \begin{tabular}{|l} 
D031 \\
D032 \\
D033 \\
D034 \\
D035 \\
D036 \\
D037
\end{tabular} & $\begin{array}{l}0.155 \\
0.134 \\
0.172 \\
0.189 \\
0.118 \\
0.056 \\
0.176 \\
\end{array}$ & $\begin{array}{l}0.61 \\
0.25 \\
0.66 \\
0.32 \\
0.18 \\
0.18 \\
0.24\end{array}$ & $\begin{array}{l}0.16 \\
0.3 \\
0.14 \\
0.27 \\
0.33 \\
0.33 \\
0.3\end{array}$ & $\begin{array}{l}0.14 \\
0.27 \\
0.12 \\
0.24 \\
0.3 \\
0.29 \\
0.27\end{array}$ & $\begin{array}{l}0.09 \\
0.18 \\
0.08 \\
0.16 \\
0.2 \\
0.2 \\
0.18 \\
\end{array}$ \\
\hline & & $\begin{array}{l}\text { Environmental } \\
\text { Greening } \\
\text { (C04) }\end{array}$ & 0.087 & \begin{tabular}{|l} 
D041 \\
D042 \\
D043 \\
D044 \\
D045
\end{tabular} & $\begin{array}{l}0.112 \\
0.084 \\
0.16 \\
0.2 \\
0.445\end{array}$ & $\begin{array}{l}0.21 \\
0.72 \\
0.34 \\
0.75 \\
0.6\end{array}$ & $\begin{array}{l}0.32 \\
0.11 \\
0.26 \\
0.1 \\
0.16\end{array}$ & $\begin{array}{l}0.28 \\
0.1 \\
0.24 \\
0.09 \\
0.14\end{array}$ & $\begin{array}{l}0.19 \\
0.07 \\
0.16 \\
0.06 \\
0.1\end{array}$ \\
\hline & & $\begin{array}{l}\text { Building energy } \\
\text { conservation } \\
\text { (C05) }\end{array}$ & 0.103 & \begin{tabular}{|l|} 
D051 \\
D052 \\
D053 \\
D054 \\
D055
\end{tabular} & $\begin{array}{l}0.092 \\
0.184 \\
0.184 \\
0.358 \\
0.183\end{array}$ & $\begin{array}{l}0.11 \\
0.35 \\
0.36 \\
0.59 \\
0.46\end{array}$ & $\begin{array}{l}0.36 \\
0.26 \\
0.26 \\
0.17 \\
0.22\end{array}$ & $\begin{array}{l}0.32 \\
0.23 \\
0.23 \\
0.15 \\
0.19\end{array}$ & $\begin{array}{l}0.21 \\
0.16 \\
0.15 \\
0.1 \\
0.13\end{array}$ \\
\hline & & $\begin{array}{l}\text { Atmospheric } \\
\text { environment } \\
\text { (C06) }\end{array}$ & 0.062 & \begin{tabular}{|l} 
D061 \\
D062 \\
D063
\end{tabular} & $\begin{array}{l}0.614 \\
0.157 \\
0.229\end{array}$ & $\begin{array}{l}0.08 \\
0.79 \\
0.48\end{array}$ & $\begin{array}{l}0.37 \\
0.08 \\
0.21\end{array}$ & $\begin{array}{l}0.33 \\
0.07 \\
0.19\end{array}$ & $\begin{array}{l}0.22 \\
0.05 \\
0.13\end{array}$ \\
\hline & & \begin{tabular}{|l} 
Acoustical \\
Environment \\
(C07) \\
\end{tabular} & 0.065 & \begin{tabular}{|l|} 
D071 \\
D072 \\
D073
\end{tabular} & $\begin{array}{l}0.517 \\
0.079 \\
0.404\end{array}$ & $\begin{array}{l}0.46 \\
0.65 \\
0.34\end{array}$ & $\begin{array}{l}0.22 \\
0.14 \\
0.27\end{array}$ & $\begin{array}{l}0.2 \\
0.13 \\
0.24\end{array}$ & $\begin{array}{l}0.13 \\
0.08 \\
0.16 \\
\end{array}$ \\
\hline & & $\begin{array}{l}\text { Water } \\
\text { Environment } \\
\text { (C08) }\end{array}$ & 0.102 & \begin{tabular}{|l} 
D081 \\
D082 \\
D083 \\
D084 \\
D085 \\
D086 \\
D087
\end{tabular} & $\begin{array}{l}0.155 \\
0.115 \\
0.102 \\
0.206 \\
0.146 \\
0.126 \\
0.15 \\
\end{array}$ & $\begin{array}{l}0.65 \\
0.66 \\
0.46 \\
0.49 \\
0.37 \\
0.53 \\
0.32 \\
\end{array}$ & $\begin{array}{l}0.14 \\
0.14 \\
0.22 \\
0.21 \\
0.25 \\
0.19 \\
0.27 \\
\end{array}$ & $\begin{array}{l}0.13 \\
0.12 \\
0.2 \\
0.19 \\
0.23 \\
0.17 \\
0.24 \\
\end{array}$ & $\begin{array}{l}0.08 \\
0.08 \\
0.13 \\
0.12 \\
0.15 \\
0.11 \\
0.16 \\
\end{array}$ \\
\hline & & \begin{tabular}{|l} 
Light \\
Environment \\
(C09)
\end{tabular} & 0.113 & \begin{tabular}{|l} 
D091 \\
D092 \\
D093
\end{tabular} & $\begin{array}{l}0.362 \\
0.229 \\
0.409\end{array}$ & $\begin{array}{l}0.29 \\
0.21 \\
0.62\end{array}$ & $\begin{array}{l}0.28 \\
0.31 \\
0.15\end{array}$ & $\begin{array}{l}0.25 \\
0.28 \\
0.14\end{array}$ & $\begin{array}{l}0.17 \\
0.19 \\
0.09\end{array}$ \\
\hline & & $\begin{array}{l}\text { Thermal } \\
\text { Environment C10) }\end{array}$ & 0.108 & $\begin{array}{l}\text { D101 } \\
\text { D102 }\end{array}$ & $\begin{array}{l}0.684 \\
0.316\end{array}$ & $\begin{array}{l}0.79 \\
0.36\end{array}$ & $\begin{array}{l}0.08 \\
0.26\end{array}$ & $\begin{array}{l}0.07 \\
0.23\end{array}$ & $\begin{array}{l}0.05 \\
0.15 \\
\end{array}$ \\
\hline & \multirow{3}{*}{$\begin{array}{l}\text { Socio- } \\
\text { ecological } \\
\text { Value } \\
\text { (B2) }\end{array}$} & $\begin{array}{l}\text { Campus } \\
\text { culture } \\
\text { (C11) }\end{array}$ & 0.277 & \begin{tabular}{|l} 
D111 \\
D112 \\
D113
\end{tabular} & $\begin{array}{l}0.417 \\
0.36 \\
0.223 \\
\end{array}$ & $\begin{array}{l}0.42 \\
0.56 \\
0.49\end{array}$ & $\begin{array}{l}0.23 \\
0.18 \\
0.2\end{array}$ & $\begin{array}{l}0.21 \\
0.16 \\
0.18\end{array}$ & $\begin{array}{l}0.14 \\
0.11 \\
0.12\end{array}$ \\
\hline & & $\begin{array}{l}\text { Campus } \\
\text { Management } \\
\text { (C12) }\end{array}$ & 0.369 & $\begin{array}{l}\text { D121 } \\
\text { D122 } \\
\text { D123 }\end{array}$ & $\begin{array}{l}0.384 \\
0.203 \\
0.412\end{array}$ & $\begin{array}{l}0.81 \\
0.64 \\
0.15\end{array}$ & $\begin{array}{l}0.08 \\
0.14 \\
0.34\end{array}$ & $\begin{array}{l}0.07 \\
0.13 \\
0.31\end{array}$ & $\begin{array}{l}0.05 \\
0.09 \\
0.21\end{array}$ \\
\hline & & $\begin{array}{l}\text { surrounding } \\
\text { environment } \\
\text { (C13) }\end{array}$ & 0.354 & \begin{tabular}{|l|} 
D131 \\
D132 \\
D133
\end{tabular} & $\begin{array}{l}0.354 \\
0.212 \\
0.434 \\
\end{array}$ & $\begin{array}{l}0.46 \\
0.06 \\
0.22 \\
\end{array}$ & $\begin{array}{l}0.22 \\
0.37 \\
0.31 \\
\end{array}$ & $\begin{array}{l}0.19 \\
0.34 \\
0.28 \\
\end{array}$ & $\begin{array}{l}0.13 \\
0.22 \\
0.19\end{array}$ \\
\hline
\end{tabular}


Step 2. Second-class fuzzy comprehensive evaluation

The fuzzy evaluation matrices of factors are as follows:

$$
\begin{gathered}
R_{B 1}=\left(R_{1}, R_{2}, R_{3}, R_{4}, R_{5}, R_{6}, R_{7}, R_{8}, R_{9}, R_{10}\right)^{T}=\left(\begin{array}{llll}
0.485 & 0.206 & 0.183 & 0.123 \\
0.267 & 0.296 & 0.264 & 0.177 \\
0.376 & 0.250 & 0.223 & 0.149 \\
0.555 & 0.178 & 0.158 & 0.109 \\
0.436 & 0.230 & 0.203 & 0.136 \\
0.283 & 0.288 & 0.257 & 0.173 \\
0.427 & 0.234 & 0.211 & 0.138 \\
0.493 & 0.204 & 0.184 & 0.119 \\
0.407 & 0.234 & 0.212 & 0.142 \\
0.654 & 0.137 & 0.121 & 0.082
\end{array}\right) \\
R_{B 2}=\left(\begin{array}{llll}
0.486 & 0.205 & 0.185 & 0.125 \\
0.503 & 0.199 & 0.181 & 0.124 \\
0.271 & 0.291 & 0.261 & 0.175
\end{array}\right) \\
\end{gathered}
$$

Then fuzzy integrated with weight vector, we obtain $R_{1}=W_{B 1} \circ R_{B 1}=(0.440,0.225,0.201,0.134)$, and $R_{2}=W_{\mathrm{B} 2} \circ R_{\mathrm{B} 2}=(0.416,0.232,0.21,0.142)$. Where $W_{B 1}, W_{B 2}$ are the weights of the two criteria.

\begin{tabular}{l|l|l|l|l|l|l|l|l|l|l|l}
\multicolumn{8}{c}{ Table 5. Pair-wise Comparison Matrix of B1 } \\
& C01 & C02 & C03 & C04 & C05 & C06 & C07 & C08 & C09 & C10 \\
\hline C01 & $(1,1,1)$ & $(3 / 2,2,5 / 2)$ & $(1 / 2,1,3 / 2)$ & $(1 / 2,2 / 3,1)$ & $(5 / 2,3,7 / 2)$ & $(2 / 5,1 / 2,2 / 3)$ & $(1,3 / 2,2)$ & $(2 / 7,1 / 3,2 / 5)$ & $(1 / 3,2 / 5,1 / 2)$ & $(2 / 7,1 / 3,2 / 5)$ \\
C02 & $(2 / 5,1 / 2,2 / 3)$ & $(1,1,1)$ & $(1 / 2,1,3 / 2)$ & $(5 / 2,3,7 / 2)$ & $(1 / 3,2 / 5,1 / 2)$ & $(2 / 5,1 / 2,2 / 3)$ & $(2 / 5,1 / 2,2 / 3)$ & $(5 / 2,3,7 / 2)$ & $(1 / 2,2 / 3,1)$ & $(2 / 7,1 / 3,2 / 5)$ \\
C03 & $(2 / 3,1,2)$ & $(2 / 3,1,2)$ & $(1,1,1)$ & $(1,1,1)$ & $(1 / 2,2 / 3,1)$ & $(2 / 3,1,2)$ & $(2 / 5,1 / 2,2 / 3)$ & $(1,3 / 2,2)$ & $(1 / 2,2 / 3,1)$ & $(1,3 / 2,2)$ \\
C04 & $(1,3 / 2,2)$ & $(2 / 7,1 / 3,2 / 5)$ & $(1,1,1)$ & $(1,1,1)$ & $(3 / 2,2,5 / 2)$ & $(2 / 3,1,2)$ & $(1 / 2,1,3 / 2)$ & $(1,3 / 2,2)$ & $(3 / 2,2,5 / 2)$ & $(1 / 2,2 / 3,1)$ \\
C05 & $(2 / 7,1 / 3,2 / 5)$ & $(2,5 / 2,3)$ & $(1,3 / 2,2)$ & $(2 / 5,1 / 2,2 / 3)$ & $(1,1,1)$ & $(2 / 7,1 / 3,2 / 5)$ & $(2 / 3,1,2)$ & $(1,3 / 2,2)$ & $(2,5 / 2,3)$ & $(5 / 2,3,7 / 2)$ \\
C06 & $(3 / 2,2,5 / 2)$ & $(3 / 2,2,5 / 2)$ & $(1 / 2,1,3 / 2)$ & $(1 / 2,1,3 / 2)$ & $(5 / 2,3,7 / 2)$ & $(1,1,1)$ & $(1,1,1)$ & $(1 / 2,1,3 / 2)$ & $(1,1,1)$ & $(2 / 3,1,2)$ \\
C07 & $(1 / 2,2 / 3,1)$ & $(3 / 2,2,5 / 2)$ & $(3 / 2,2,5 / 2)$ & $(2 / 3,1,2)$ & $(1 / 2,1,3 / 2)$ & $(1,1,1)$ & $(1,1,1)$ & $(2 / 5,1 / 2,2 / 3)$ & $(5 / 2,3,7 / 2)$ & $(5 / 2,3,7 / 2)$ \\
C08 & $(5 / 2,3,7 / 2)$ & $(2 / 7,1 / 3,2 / 5)$ & $(1 / 2,2 / 3,1)$ & $(1 / 2,2 / 3,1)$ & $(1 / 2,2 / 3,1)$ & $(2 / 3,1,2)$ & $(3 / 2,2,5 / 2)$ & $(1,1,1)$ & $(2 / 3,1,2)$ & $(1,1,1)$ \\
C09 & $(2,5 / 2,3)$ & $(1,3 / 2,2)$ & $(1,3 / 2,2)$ & $(2 / 5,1 / 2,2 / 3)$ & $(1 / 3,2 / 5,1 / 2)$ & $(1,1,1)$ & $(2 / 7,1 / 3,2 / 5)$ & $(1 / 2,1,3 / 2)$ & $(1,1,1)$ & $(1 / 2,1,3 / 2)$ \\
C10 & $(5 / 2,3,7 / 2)$ & $(5 / 2,3,7 / 2)$ & $(1 / 2,2 / 3,1)$ & $(1,3 / 2,2)$ & $(2 / 7,1 / 3,2 / 5)$ & $(1 / 2,1,3 / 2)$ & $(2 / 7,1 / 3,2 / 5)$ & $(1,1,1)$ & $(2 / 3,1,2)$ & $(1,1,1)$ \\
\hline
\end{tabular}

Step 3. Third-class fuzzy comprehensive evaluation:

The third-grade fuzzy evaluation matrix is $R_{A}=\left(R_{1} R_{2}\right)^{T}$, then the fuzzy integrated results are $\Omega=\left(\omega_{1}, \omega_{2}, \omega_{3}, \omega_{4}\right)=W_{A} \circ R_{A}$ $=(0.435,0.226,0.203,0.136)$, where $\omega_{i}$ represents the degree of the ecological value of the university campus belonging to assessment class $V_{i}$, here we chose the weights $W_{A}=(0.75,0.25)$. In order to keep the values authoritative and relatively stable, we invited several experts to evaluate the weights for criteria B1 and B2, and obtained the results by averaging their values. We defined the linguistic variables as follows: $H=\left(h_{1}, h_{2}, h_{3}, h_{4}\right)=($ excellent, good, moderate, ineligible $)=(1,0.8,0.6,0)$.

Then we obtain the comprehensive assessment value $M$ of the ecological value of the university campus. It can be expressed as $M=\Omega \sqcap H^{T}=0.738$,because $0.6<0.738<0.8$, so the result of the assessment is moderate $(\star \star)$.

In order to make the assessment more reasonable, we selected 10 groups to evaluate the university campus and give each group the weight $a_{i}(i=1, \cdots, 10)$. We obtained the 10 results of the evaluation which are $M_{1}, M_{2} \cdots M_{10}$, then we got the final result of the assessment as $\sum_{i=1}^{10} a_{i} \times M_{i}$. It is obvious that the calculation of our work is in a large amount, so we complied a Mathematica package to finish all the calculation work.

\section{Conclusions}

We consider that people are often uncertain in assigning the evaluation scores in conventional AHP. So we established a model for assessment of ecological value of university campuses based on the FAHP, which can reflect their subjective feelings and objective environmental conditions more comprehensively. The hierarchy in the model contains 2 criteria, 13 factors and 55 subfactors. The method used in our model can be applied to do other evaluations. The result of the model we selected verified that the 
method we use is feasible. Compared with AHP, the amount of calculation of FAHP does not increase for avoiding calculating the characteristic values and vectors of comparision matrice. Furthermore, the Mathematica program we compiled is of high effectiveness and generability. We can discuss other similar evaluation with FAHP.

\section{References}

Chang D.Y., 1996. Applications of the extent analysis method on fuzzy AHP, European Journal of Operational Research, Vol. 95, pp. 649-655.

Conway T.M., Dalton C., Loo J., Benakoun L. 2008. Developing ecological footprint scenarios on university campuses-A case study of the University of Toronto at Mississauga, International Journal of Sustainability in Higher Education. Vol. 9, No. 1, pp. 4-20.

Han C.F. and Zhang Q.H., 2003. Multi attributes synthesis evaluation method for monomer house property judgment, Journal of Tongji university, Vol. 31, pp. 1477-1481, Dec.

Hus T.H. and Nian S.H., 1997. Interactive fuzzy decision aided systems -A case on public transportation system operations, Journal of Transportation Taiwan, Vol. 10, pp. 79-96.

Kahraman C., Cebeci U. and Ulukan Z., 2003. Multi-criteria supplier selection using fuzzy AHP, Logistics Information Management, Vol. 16, pp. 382-394.

Kahraman C., Ertay T. and Buyukozkan G., 2006. A fuzzy optimization model for QFD Planning process using analytic network approach,European Journal of Operational Research, Vol. 171, pp. 390-411.

Lious T.S. and Wang M.J.J., 1992. Ranking fuzzy numbers with integral value, Fuzzy Sets and Systems, Vol. 50, pp. 247-255.

Zaddeh L.A., 1965. Fuzzy sets. Information and Control, Vol. 8, pp. 53-338.

Zhang D.L., 2006. The new focus of green ecological residential property, China Construction News, June.

Zhang H.Q. and Zhan Z.F., 2004. Synthetical evaluation mode for residential quarters, Journal of Hehai University (Natural Sciences), Vol. 32, pp.716-718, Nov.

Zimmermann H.J., 1987. Fuzzy Sets, Decision Making and Expert Systems, Kluwer Academic Publishers, Boston.

\section{Biographical notes}

Ms. HongWei Chen is currently working as an Engineer in Office of Campus Construction, Tianjin Polytechnic University, Tianjin, China. After receiving the degree of Bachelor of Engineer on Architecture, she began her work as an Engineer on campus construction. She has been studying the research on ecological campuses for several years.

Received January 2010

Accepted January 2010

Final acceptance in revised form September 2010 